\title{
VITALIJA TRUSKAUSKAITE
}

Vytautas Magnus University, Kaunas

\section{Social trauma and the theatre: a study of the formation of a non-conformist identity}

Key words: pantomime theatre, Judita Vaiciunaite, Giedrius Mackevicius, social trauma

\section{Summary}

The present article aims to analyse the social trauma implicit in the representation of the nonconformist identity formation in Judita Vaiciunaite's play The Siege (Lithuanian Apsiaustis) directed by Giedrius Mackevicius. The play reflects on the experiences and inner states of characters as they struggle to survive in a seized city, wherein the motif of the seized city alludes to the political situation of Kaunas as a city seized by the totalitarian system. The play was performed by an amateur group in 1971 in the Kaunas Trade Unions Palace of Culture. The study relies on trauma studies by Danute Gailiene for the analysis of Giedrius Mackevicius' debut experience; also it refers to the semantics of Judita Vaiciunaite's play The Siege. In the staging of The Siege in 1971, on the contrary, the universal thematic dimension of this drama was emphasized.

Giedrius Mackevicius (1945-2008), an actor in a mime troupe at Kaunas Musical Theatre, started his career as a stage director between 1970 and 1972. Kaunas cultural space provided him with a space for his directorial debut, an experience on which he built to found the Plastic Drama Theatre in Moscow after he had left the Lithuanian theatrical 
scene. Several years of working at the theatre in Kaunas was a very positive and inspiring experience. It acquired new meaning in further theatre related activities: studying at the Russian State Institute for Theatre Arts (GITIS) in the class of the famous educator, Mary Knebel and in the staging of performances that implement elements of movement, music, art, and the psychology of performing arts, as well as performances that incorporate modern technologies. These performances were staged at the Cultural Centre Palace of the Nuclear Energy Institute in Moscow. What began as a smaller-scale studio work developed into a professional physical theatre which became known as the Plastic Drama Theatre. Moscow audiences responded very well to the performances directed by Giedrius Mackevicius. The success was not only due to a brave choice of genre but also due to the original treatment of the subject matter. In this theatre, Giedrius Mackevicius directed over ten performances; more than twice as many were directed in other theatres. These included joint projects with state theatres, work as an external consultant, and work as a movement director for a drama theatre. In 1993, Mackevicius started working as director in the then newly-founded Oktader theatre.

The present article aims to analyse the social trauma implicit in the representation of the nonconformist identity formation in Judita Vaiciunaite's play The Siege (Lithuanian Apsiaustis) directed by Giedrius Mackevicius. The play reflects on the experiences and inner states of characters as they struggle to survive in a seized city, wherein the motif of the seized city alludes to the political situation of Kaunas as a city seized by the totalitarian system. The play was performed by an amateur group in 1971 in the Kaunas Trade Unions Palace of Culture.

Thus far, the circumstances of the directorial debut of Giedrius Mackevicius, an actor at the Pantomime Theatre have received little critical attention. The majority of scholarship that mentions the name of Giedrius Mackevicius is actually focused on the analysis of Modris Tenisonas' work in pantomime troupes at the drama and musical theatres in Kaunas. More research has been conducted on Giedrius Mack- 
evicius' work as a director at Moscow Plastic Drama Theatre. Mackevicius' book, published posthumously in Moscow in 2010, provided a wealth of information about the circumstances of his directorial debut. The abundant archives of photos and video recordings of Giedrius Mackevicius' performances also served as a useful means allowing reconstruction of the performances. The present study relies on trauma studies by Danute Gailiene for the analysis of Giedrius Mackevicius' debut experience; also it refers to the semantics of Judita Vaiciunaite's play The Siege.

The work in the Pantomime Troupe at Kaunas Musical Theatre was not the only thing that related Modris Tenisonas and Giedrius Mackevicius. Mackevicius, who was then an actor who also had a degree in biochemistry, supported the activities of the troupe director Modris Tenisonas. One of the most notably contributions was Mackevicius' help and advice in the creation and implementation of the programme of the Pantomime Troupe. He was also the editor of the newsletter paper which was intended to communicate and reflect the main artistic and intellectual interests of the troupe. The newsletter paper, in accordance with the habitual practice at the time, was issued in the form of a bulletin board. It provided a platform for publicizing the most recent information on important theatre events in Western Europe which were concealed or forbidden by the Soviet press: the theory and practice of the theatre by the Polish stage director Jerzy Grotowski, the performances by the founder of the visual motion theatre, Józef Szajna, and works by composers banned by the Soviet regime. Despite the Soviet censorship and restrictions, the contents of the newsletter paper reflect the aspiration of Kaunas Pantomime Troupe towards intellectual, professional, and spiritual freedom (Tenisonas, 2012). The Pantomime troupe introduced into the Lithuanian scene the technique of collage which was used in performances of physical theatre. The techniques used by Kaunas Pantomime Troupe integrated European art traditions into their performances with diverse philosophical contexts. Their techniques intertwined the music of Gustav Mahler and the philosophy of 
Zen Buddhism, yoga, as well as the European avant-garde painting and theatre practices. Theatre critic Edgaras Klivis described the activity of Kaunas Pantomime Troupe during the period of 1967-1972 as a new moral and behavioural paradigm in the Soviet theatre (Klivis, 2012).

Alongside with working in the pantomime troupe of Kaunas $\mathrm{Mu}$ sical Theatre, Giedrius Mackevicius started to work as a stage director and educator at the Literary Theatre Studio in Kaunas Trade Unions Palace of Culture. The Literary Theatre Studio was formed by students of senior years of the secondary school, students of higher education and members of informal groups. They listened to lectures of famous Lithuanian and Russian art critics, held presentations on selected issues of European art, and read Lithuanian literature. Lithuanian contemporary poetry was most popular among them.

The Studio's debut play The Wreath (Lithuanian Vainikas), staged in 1970, was an outcome of its members' interest in Lithuanian contemporary poetry. The play was directed by Giedrius Mackevicius who was the author of the poetic composition: he arranged excerpts of Lithuanian contemporary poetry into a single drama. In the play The Wreath, poetry reading was performed in the background of impressive vocal, plastic and visual improvisation.

The poetic texts, chosen by the young people of the Literary Theatre Studio were noncanonical, by extension they were not part of the school or university curriculum. The choice of the poets and their poetry destroyed the hierarchies of literature established by the power structures of the Soviet era. As far back as 1970, members of the studio demonstrated adherence to values which were completely different from those advocated and/or prevalent at school and other Soviet social contexts. For young people, the studio served as a milieu where they could experience a sense of freedom and which allowed them to realize their creativity. An important point to make here is that a new stage may have started in the professional relationship between the previously mentioned Modris Tenisonas and Giedrius Mackevicius. Just to mention, Modris Tenisonas attended the final rehearsal before the first showing 
of The Wreath; he was then directing 20th Century Capriccio. At the time both artists were staging plays about the impact of the totalitarian regime. This oppositional stance is what brought them together. Their intense discussions on thematic and methodological issues were aimed at finding creative solutions to questions related to the representation of inner states of people under a spiritual siege.

Judita Vaiciunaite's play The Siege was born out of her poetry. Her poetry had been recited by members of the studio who perceived her texts as representing states of being of youth in the modern city. The poetic texture of Vaiciunaite's texts accommodates ancient mythological heroes, characters from Lithuanian social and cultural history, and spiritual experiences of the contemporary artist. For people living under the Soviet rule, the lingering memories of the integrity of the world, undivided by the concrete and metal Berlin Wall, was a bulwark in their struggle against the imposed ideology.

The poetry of Judita Vaiciunaite provides the apologists of difference, that is, people who emphasize their opposition to moral and spiritual values inherent in the Soviet ideology with a social, artistic, and moral base for self-identification. The play, written in 1968, though unpublished, circulated all over Lithuania in the form of a manuscript. It was valued as a text which takes beyond the realities of the Soviet life. The interest of the Literary Theatre Studio in Vaiciunaite's play served as a form of publicizing the text, albeit among the audience that was then regarded as marginal youth.

It is important to consider what techniques of theatrical presentation were chosen to convey the non-conformist position. The cast of the performance was not aware that the play The Siege, which later became part of the collection of Judita Vaiciunaite's dramas Spring Flute (Lithuanian Pavasario fleita), published in 1980, ten years after the play The Siege was staged by Giedrius Mackevicius, contained a dedication note. The note, which may have been from the author or the editors, said that the play was dedicated to victims of fascism. Prisoners' chorus embody the idea of a spiritual seize which is the underlying motif in the play. 
The singers wore uniforms of Nazi concentration camp prisoners, just as some characters of Jerzy Grotowski and Józef Szajna’s plays. The costumes were intended to symbolize the idea of both artistic and political imprisonment that had become a permanent condition of much of the $20^{\text {th }}$ century. One of the reasons for taking a retrospective glance at this performance is because it was among the first to employ the metaphor of imprisonment which the spectators perceived as their spiritual experience.

In Judita Vaiciunaite's play, the director highlighted the mythologeme of imprisonment as a psychological siege, not the historical artefacts of imprisonment. Even from the perspective of those times, the repeated emphasis by current critics on the dedication to the play in 1980 as explaining the problematic issues in the work seem especially naive (Slekiene, 2012). In the staging of The Siege in 1971, on the contrary, the universal thematic dimension of this drama was emphasized.

On a platform in the center of the audience, the young participants in the performance uttered Vaiciunaite's words with intense passion. There was no censorship there, no fear; only the rules of opening up and of confession were acknowledged. Indeed, this is what Modris Tenisonas called this performance - a theatre of confession (Kochanskyte, 2012). As a non-professional actor he also perceived a decisive willingness to share experience so that through Vaiciunaite's work resulted in a poetic history of loss and the emotions of existing in a psychological siege.

All the characters in this drama are living in a state of siege: Wasteland. A massive and apparently dead city wall appears as in a mist. Pursuits are going on - the ones that over thousands of years took place an uncountable number of times (Vaiciunaite 1980, 31). Next to the walls of the dead city, the writer sees people who are being hunted and calls them prisoners or even a prisoners' chorus, singling out several persons and attributing to them different powers in the marathon of pursuit.

The Commandant, whose role the director gave to a woman, the actress Virginija Kochanskyte, was given the power to lose: Achilles losing the sensation of intimacy with another person. Vaiciunaite attri- 
buted to Achilles the most painful losses, to lose a friend: and in every shoulder I am haunted by the shoulder of my close friend .../ But a black/ overwhelming sky haunts me like the vault of a cellar ... (Vaiciunaite 1980, 42). Achilles will also have to lose a beloved woman: You have exchanged me for death (Vaiciunaite 1980, 44).

What survives in this history of pursuit, siege and losses? It is the drama's chorus, not the characters in the drama, who is predestined to know this. In Vaiciunaite's play The Siege the chorus is an ancient Delphic oracle who understands the end and the meaning of this history of losses. The intuition of the end is expressed by the lips of the chorus through the metaphor of the breaking sun: And the sun - the only time breaks (Vaiciunaite 1980, 42). In the mythology of siege only memories remain. It might be said that these are the only consolation for human beings from culture at the end of time.

In Judita Vaiciunaite's plays memory reaches as far as the history of culture can afford. For her, the history of losses begins with Achilles. It is only after he has slain the Amazon Penthesilea that Achilles discovers the beauty of a woman. Further, there are other signs of loss, inevitably shaped by death and fragmented, through the passing of fatal time. In the history of loss there is only one privilege - to remember the lost lover (Penthesilea, referred to as one of the numbered prisoners in the play), a mother's hands (I am kissing your hands), to discover the tragedy of a moment (I killed my love myself at the same time that I found it) and, in the end, to acknowledge that defeat lies in every victory while every defeat can be a victory. The youth chorus, repeating the final words of the play, expressed the writer's vision: We, from pure pain (...) Deadly scream - through clenched teeth (Vaiciunaite, 1980, 45).

Much later Giedrius Mackevius summarizes the professional experience he gained from this directorial debut, in the texts published after this death. He had to supplement the lack of professionalism in the art of acting of his performers with directorial means: the pace of the performance and the rhythm of an expressive form of drama, providing meaningful structures of space and time (Mackevicius, 2010, 520). As 
a director, he expanded and de-theatricalized the performance space to reflect the experience of trauma: the performers kept to the ritual space of a circle, which was associated with the siege, the city and the theatrical narrative: in addition, the actors opened themselves up with confession, scenes in which a spectator, chosen by the specific actor, became the confessor to whom words of despair were uttered. In this use of direct contact between the actor and the spectator, it is possible to discern a form of psychotherapy; the remembrance of pain and wounds was transferred from one cultural space into another and became a kind of social discourse (Gailiene, 2008, 36). In this theatrical act of transference one can perceive the intention to transfer social trauma and personal space in to a public one, to experience it and then share it with the spectators, so also creating the possibility for the search for a new identity. As a director, Mackevicius attempted to directly link the spectators with the creators of the performance, leaving the initiative to the actors, who were the first to publically express their experience of trauma and its meanings.

Then, after the performance, one would hear reactions of wonder - why do these Komsomol (Communist Youth) members speak about the world so tragically? Today, remembering the first staging of Judita Vaiciunaite's play The Siege, in memory this performance is seen within the context of events in the near future. In the spring of 1972 in Kaunas, many more performances took place that was assessed as highly improper for communism. Non-conformist identity moved beyond the space of the theatre hall and poured out into the streets of Kaunas. The official response to the non-conformist attitude of people working in the theatre was quick: Jonas Jurasas and Modris Tenisonas lost their posts as directors and their theatrical work in Lithuania was terminated. Giedrius Mackevicius, together with the entire Pantomime Theatre troupe, also had to search for a new space for theatrical work. Mackevicius, having directed Vaiciunaite's play The Siege, managed to save himself from persecution which especially started in 1972 after a Kaunas teenager, Romas Kalanta publically burnt himself to death in the square in front 
of the Musical Theatre and hundreds of young protestors flooded the streets of the city. Mackevicius then changed his status as a biochemist and an actor in the Pantomime Theatre to become a first-year student of directing in the Moscow GITIS (State Institute of Theatre Art). Giedrius Mackevicius's further creative activity in Moscow gave him fame as an underground actor.

\section{Conclusions}

In 1971-1972 theatrical activity in Kaunas revealed the problematic of an open confrontation with the Soviet regime.

In Jonas Jurasas' and Modris Tenisonas' staging of Barbora Radvilaite and $20^{\text {th }}$ Century Capriccio, audiences were introduced to the narrative of not conforming to the normative aesthetics of socialist realism.

In 1971 a performance based on Judita Vaiciunaite's poetic drama The Siege was directed by GiedriusMackevicius and staged in the amateur Literary Theatre. The narrative was treated as the traumatic experience of spiritual siege.

Using the metaphorical language of the play, the theatre director Giedrius Mackevicius, used the paradigm of imprisonment in the way actors performed the characters so that a feeling of traumatic siege was experienced. Interaction between the actors and the spectators of this play revealed the psychological separation of the creators and defined their condition as one of not accepting the current social environment.

\section{Bibliography}

Gailienė D., 2008, Ka jie mums padaré?, Vilnius.

Klivis E., 2003, Modris Tenisonas ir nonkonformizmas Lietuvos teatre.// Kauno Istorijos metraštis, t. IV. Website: http://www.vdu.lt/Leidiniai/metrastis/nr4.html. Accessed: 2012.07.01.

Мацкявичюс Г., 2010, Преодоление, Москва.

Storik N., 2008, Amžinasis smuikininkas// Lietuvos žinios. Websi-

te: http://webcache.googleusercontent.com/search?q=cache:lQa- 
IieI6msYJ:www.menufaktura.lt/\%3Fm\%3D1024\%26s\%3D59990 + giedrius + mackevicius $\& \mathrm{~cd}=10 \& \mathrm{hl}=\mathrm{lt} \& \mathrm{ct}=\mathrm{clnk} \& \mathrm{gl}=\mathrm{lt} . \quad$ Accessed: 2012.06.14.

Šlekienė V., 2009. Moters pasaulis Juditos Vaičiūnaitès kūryboje Website: http://www.biblioteka.vpu.lt/zmogusirzodis/PDF/literaturologija/2009/slek36-43.pdf Accessed: 2012.06.26.

Truskauskaitè V., 2012, Interviu su aktoré Virginija Kochanskyte, Kaunas, 03.06.2012.

Truskauskaitė V., 2012, Interviu su režisieriumi Modriu Tenisonu, Kaunas, 23.05.2012.

Vaičiūnaitè J., 1980, Pavasario fleita, Vilnius. 